In Cooperation with Environment Canada's National Water Research Institute and the Great Lakes Protection Fund

\title{
Calculation of Streamflow Statistics for Ontario and the Great Lakes States
}

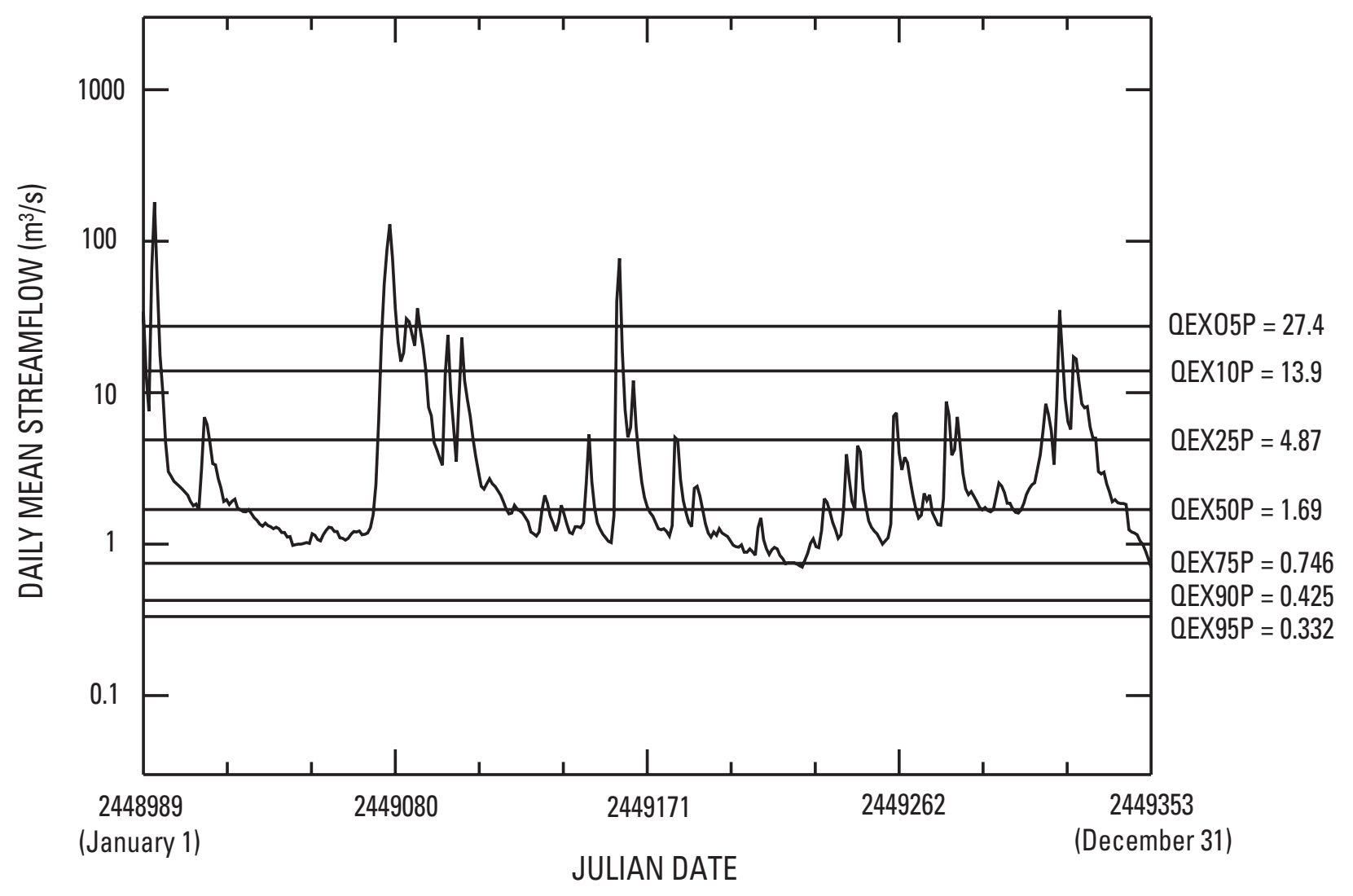

Open File Report 2005-1295 
Cover. Calculated values of the flow-duration statistics (OEX05P, QEX10P, QEX25P, QEX50P, QEX75P, OEX90P, and QEX95P) for the Nith River at New Hamburg relative to daily mean streamflow for 1993. Created by Brian P. Neff and Andrew R. Piggott, July 5, 2005. 


\section{Calculation of Streamflow Statistics for Ontario and the Great Lakes States}

By Andrew R. Piggott* and Brian P. Neff

* National Water Research Institute, Environment Canada

Burlington, Ontario, Canada

Prepared in Cooperation with Environment Canada's National Water Research Institute and the Great Lakes Protection Fund

Open File Report 2005-1295

U.S. Department of the Interior

U.S. Geological Survey 


\section{U.S. Department of the Interior \\ Gale A. Norton, Secretary}

\section{U.S. Geological Survey \\ P. Patrick Leahy, Acting Director}

U.S. Geological Survey, Reston, Virginia: 2005

For sale by U.S. Geological Survey, Information Services
Box 25286, Denver Federal Center
Denver, CO 80225
For more information about the USGS and its products:
Telephone: 1-888-ASK-USGS
World Wide Web: http://www.usgs.gov/

\footnotetext{
Any use of trade, product, or firm names in this publication is for descriptive purposes only and does not imply endorsement by the U.S. Government.

Although this report is in the public domain, permission must be secured from the individual copyright owners to reproduce any copyrighted materials contained within this report.

Suggested citation:

Piggott, A.R., Neff, B.P., 2005, Calculation of Streamflow Statistics for Ontario and the Great Lakes States: U.S. Geological Survey Open File Report 2005-1295, 12 p.
} 


\section{CONTENTS}

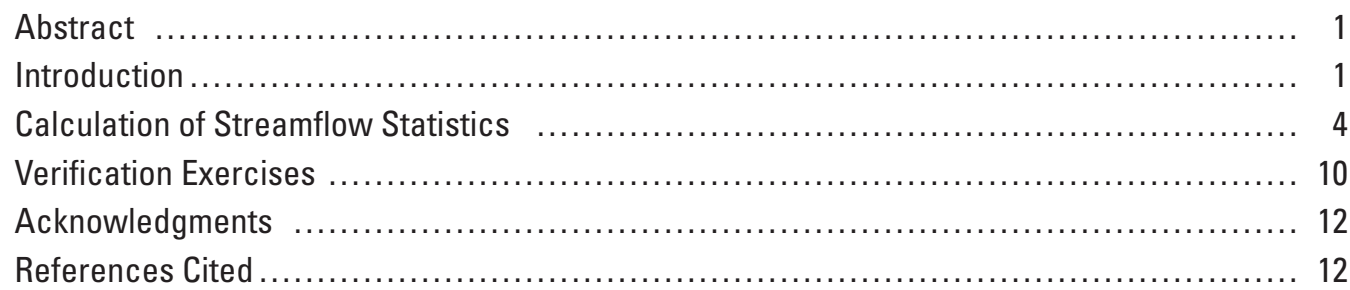

Appendix: Streamflow Statistics (Attached CD)

\section{FIGURES}

1. Chart showing the temporal distributions of the daily mean streamflow data for Ontario and the Great Lakes states measured in terms of the number of values of daily mean streamflow per year .............................. 2

2. Map showing spatial distribution of the streamflow data $\ldots \ldots \ldots \ldots \ldots \ldots \ldots \ldots$ 3-5. Charts showing:

3. Calculated values of the maximum and mean statistics for the Nith River at New Hamburg, Ont. relative to total streamflow for 1993.

4. Calculated values of the flow-duration statistics for the Nith River at New Hamburg, Ont. relative to total streamflow for 1993

5. Calculated values of the $n$-day frequency high-flow and low-flow statistics for the Nith River at New Hamburg, Ont. relative to total streamflow for 1993

\section{TABLES}

1. First 25 records of the streamflow gage file $02 \mathrm{GA} 018.000 \quad \ldots \ldots \ldots \ldots \ldots \ldots \ldots$

2. Perl programming script file iowdm.pl used to translate ASCII text files into

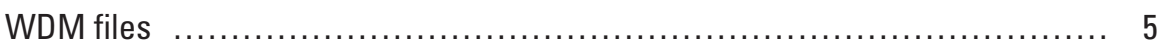

3. Command file iowdm.log used to translate ASCII text files into WDM files $\ldots \ldots .5$

4. Perl programming script file basic.pl, used to calculate the streamflow statistics ................................................................ 5

5. Command file basic.log, used to calculate the streamflow statistics ............ 6

6. Command file annie.log, used to extract the streamflow statistics from the

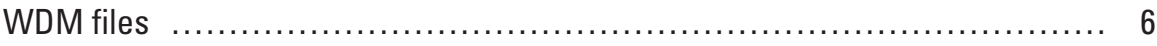

7. Perl script duration.pl, used to calculate the flow-duration statistics........... 6

8. Command file duration.template, used to derive duration.log ................. 7

9. Script frequency.pl, used to calculate the $n$-day frequency statistics $\ldots \ldots \ldots . .8$

10. Command file frequency.log, used to calculate the $n$-day frequency statistics ... 9 


\section{Conversion Factors}

Inch/Pound to SI

\begin{tabular}{lcl}
\hline Multiply & By & To obtain \\
\hline \multicolumn{3}{c}{ Length } \\
\hline inch (in.) & 25.4 & millimeter $(\mathrm{mm})$ \\
foot (ft) & 0.3048 & meter $(\mathrm{m})$ \\
mile (mi) & 1.609 & kilometer $(\mathrm{km})$ \\
\hline \multicolumn{3}{c}{ Area } \\
\hline square mile $\left(\mathrm{mi}^{2}\right)$ & 2.590 & square kilometer $\left(\mathrm{km}^{2}\right)$ \\
\hline & Flow rate & \\
\hline cubic foot per second $\left(\mathrm{ft}^{3} / \mathrm{s}\right)$ & 0.02832 & cubic meter per second $\left(\mathrm{m}^{3} / \mathrm{s}\right)$ \\
\hline
\end{tabular}

\section{Miscellaneous Abbreviations and Glossary}

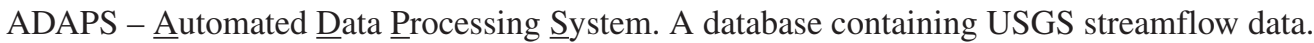

ANNIE - Interactive hydrologic analyses and data management software (Flynn and others, 1995). A USGS program designed to help users interactively store, retrieve, list, plot, check, and update spatial, parametric, and time-series data for hydrologic models and analyses. http://water.usgs.gov/cgi-bin/man_wrdapp?annie

ASCII - $\underline{\text { American }} \underline{\text { Standard }} \underline{\text { Code for }}$ Information Interchange.

DFLOW - Windows-based tool developed by the United States Environmental Protection Agency to estimate user selected design streamflows for low-flow analysis and water quality standards. http://epa.gov/waterscience/dflow/

ESRI - Environmental Systems Research Institute. http://www.esri.com/

FORTRAN - FORmula TRANslation. A high-level programming language for mathematical and scientific purposes.

g77 FORTRAN compiler -A program that translates programs written in FORTRAN into machine language so that they can be executed.

GLI - Graphics L Language Interpreter. A graphics system that offers an environment for plotting complex data sets and displaying images. http://iffwww.iff.kfa-juelich.de/gli/

HYDAT - A CD-ROM published by Environment Canada which provides access to $\underline{\mathrm{HY}}$ dro logic DATa contained in the Canadian National Water Data Archive. http://www.wsc.ec.gc.ca/products/hydat/main_e.cfm?cname=hydat_e.cfm

IOWDM - Input and Output for a Watershed Data Management (WDM) file (Lumb and others, 1990). IOWDM is designed to reformat data to and from a WDM file. Data in selected WATSTORE card-image formats and flat file formats can be added to a WDM file using this software. http://water.usgs.gov/software/iowdm.html 
LFA - Low Flow Frequency Analysis Package. A hydrologic software package used for the analysis and graphing of the frequency of occurrence of selected low flows, based on streamflow records at one or more gaging sites.

http://www.trentu.ca/wsc/software.shtml

LIBANNE - (Kittle and others, 1989) A collection of related libraries for use in hydrologic applications that provides a WDM data base, graphics, and interactive user interface (AIDE) for hydrologic applications. http://water.usgs.gov/software/libanne.html

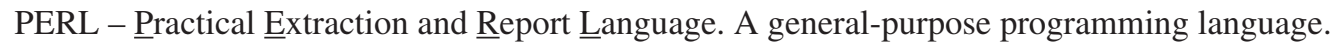
http://www.perl.com/

Red Hat Linux - A computer operating system. http://www.redhat.com/

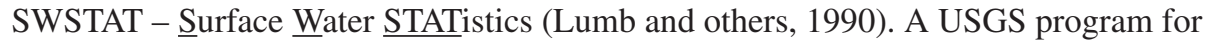
developing streamflow statistics, http://water.usgs.gov/software/swstat.html

WATSTORE - The National WATer Data STOrage and REtrieval System. Established in 1972 to provide an effective and efficient means for the processing and maintenance of water data collected through the activities of the U.S. Geological Survey and to facilitate release of the data to the public.

http://ak.water.usgs.gov/Publications/water-data/WY96/watstore.htm

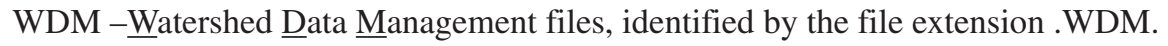

Basic streamflow statistics

CNTVAL - Number of values of streamflow

MAXVAL - Maximum of the values of streamflow

MEANVL - Mean of the values of streamflow

MINVAL - Minimum of the values of streamflow

STDDEV - Standard deviation of the values of streamflow

Flow-duration statistics

QEX05P - 5 percentile flow exceedance

QEX10P - 10 percentile flow exceedance

QEX25P - 25 percentile flow exceedance

QEX50P - 50 percentile flow exceedance

QEX75P - 75 percentile flow exceedance

QEX90P - 90 percentile flow exceedance

QEX95P - 95 percentile flow exceedance

$\mathrm{N}$-day frequency statistics

H01005 - 1-day 5-year recurrence interval high-flow

H01025 - 1-day 25-year recurrence interval high-flow

H01050 - 1-day 50-year recurrence interval high-flow

H01100 - 1-day 100-year recurrence interval high-flow

L07002 - 7-day 2-year recurrence interval low-flow

L07005 - 7-day 5-year recurrence interval low-flow

L07010 - 7-day 10-year recurrence interval low-flow

L07020 - 7-day 20-year recurrence interval low-flow 



\title{
Calculation of Streamflow Statistics for Ontario and the Great Lakes States
}

\author{
By Andrew R. Piggott and Brian P. Neff
}

\section{Abstract}

Basic, flow-duration, and n-day frequency statistics were calculated for 779 current and historical streamflow gages in Ontario and 3,157 streamflow gages in the Great Lakes states with length-of-record daily mean streamflow data ending on December 31, 2000 and September 30, 2001, respectively. The statistics were determined using the U.S. Geological Survey's SWSTAT and IOWDM, ANNIE, and LIBANNE software and Linux shell and PERL programming that enabled the mass processing of the data and calculation of the statistics. Verification exercises were performed to assess the accuracy of the processing and calculations. The statistics and descriptions, longitudes and latitudes, and drainage areas for each of the streamflow gages are summarized in ASCII text files and ESRI shapefiles.

\section{Introduction}

Streamflow statistics calculated using streamflow data summarize the observed flow regime and are frequently cited in water-resource studies. This report describes the calculation of consistent and up-to-date streamflow statistics for streamflow gages in Ontario and the Great Lakes states.

Daily mean streamflow data for all current and decommissioned streamflow gages in Ontario were extracted from the HYDAT CD for 2000 (Environment Canada, 2002). Attributes such as the descriptions, longitudes and latitudes, and drainage areas for the streamflow gages were also extracted from the HYDAT CD. Streamflow data and attributes for 779 streamflow gages in Ontario were retained for processing.
Daily mean streamflow data for the Great Lakes states (Illinois, Indiana, Michigan, Minnesota, New York, Ohio, Pennsylvania, and Wisconsin) were extracted from the U.S. Geological Survey's (USGS) ADAPS database. Attributes for all current and decommissioned streamflow gages in the Great Lakes states were extracted from the USGS's National Water Information System (NWIS) at http://nwis.waterdata.usgs. gov/usa/nwis/discharge. Streamflow data for 3,157 streamflow gages in the Great Lakes states were retained for processing; however, attributes analogous to those determined for Canadian streamflow gages were determined for only 3,151 of these streamflow gages. The statistics that were calculated for the remaining six streamflow gages are not included in the final summaries. Length-of-record streamflow data was extracted in both cases. The data for Ontario and the Great Lakes states are for the periods ending on December 31, 2000 and September 30, 2001, respectively.

Figure 1 shows the temporal distribution of the data for Ontario and the Great Lakes states measured in terms of the number of daily mean streamflow values per year. The earliest year of observation is 1860 for Ontario and 1884 for the Great Lakes states. There are $7,202,212$ daily mean streamflow values for Ontario and $30,864,754$ for the Great Lakes states. The averages of the years of observation weighted relative to the number of values of streamflow-per-year are 1971 and 1966 for Ontario and the Great Lakes states, respectively. Therefore, the temporal distributions of the data are similar despite the large contrast in the total numbers of values.

Spatial distributions of the data measured in terms of the locations of the streamflow gages are shown in figure 2 . The distributions of streamflow gages across the Great Lakes states and in southern Ontario are similar, and the reported values of drainage areas have 


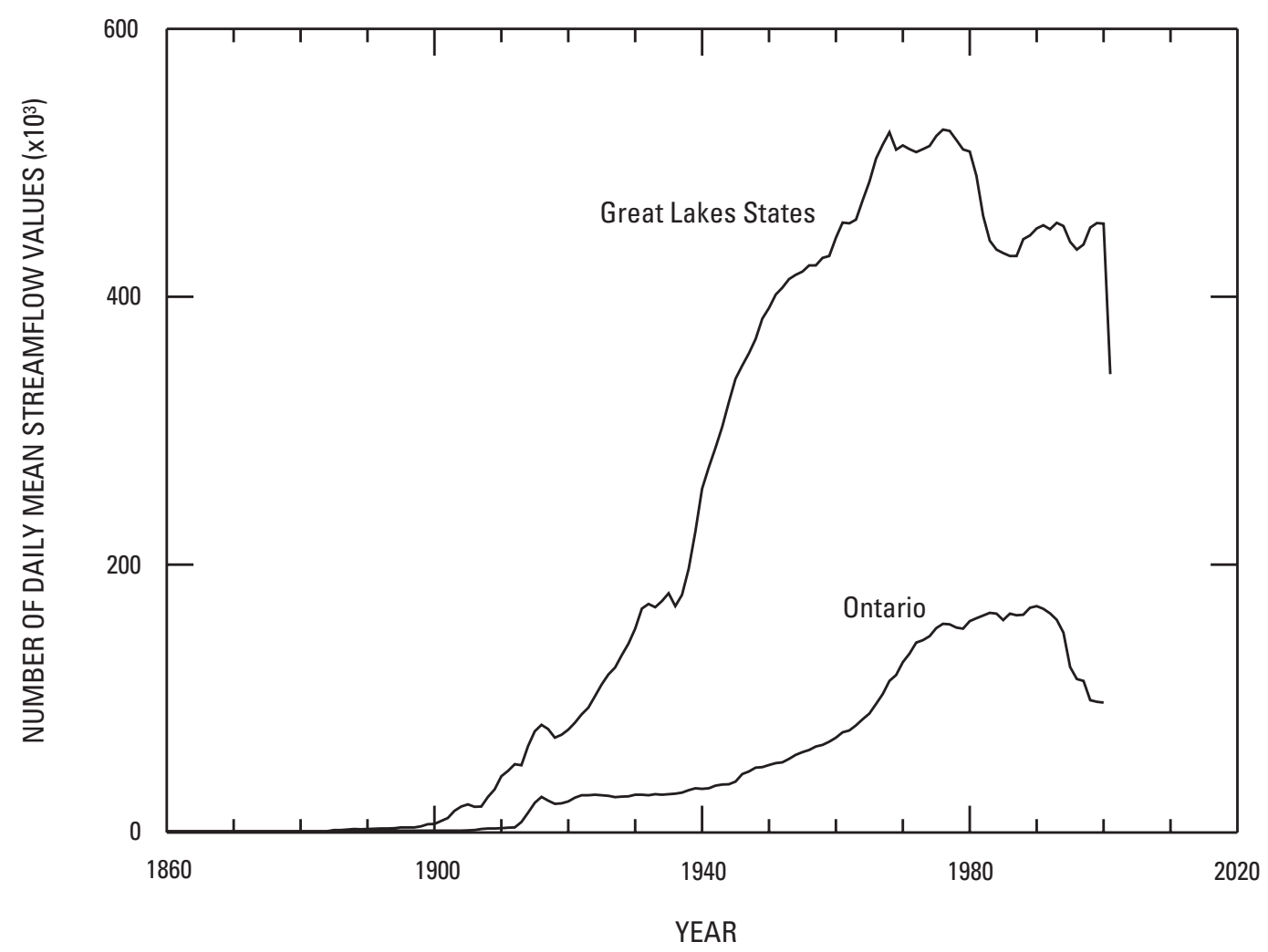

Figure 1. Temporal distributions of the daily mean streamflow data for Ontario and the Great Lakes states measured in terms of the number of values of daily mean streamflow per year.

median values of $316 \mathrm{~km}^{2}$ and $246 \mathrm{~km}^{2}$ for Ontario and the Great Lakes states, respectively. Streamflow gages are relatively sparsely distributed and gaged drainage areas are slightly larger in northern Ontario compared to the eight Great Lakes states.

The data for Ontario and the Great Lakes states were extracted from the two databases in different formats. Linux shell and PERL programming were used to organize the data into consistent formats. Julian dates were inserted into the data to facilitate the ordering of the information by date where, for example, the Julian dates 2433376 and 2433377 correspond to the calendar dates April 4 and 5, 1950. The data were partitioned into one ASCII text file per gage where the file name indicates the gage number and where the data are arranged in ascending order relative to the Julian dates. Table 1 lists the first 25 records of the file 02GA018.000, which contains the data for Water Survey of Canada streamflow gage 02GA018, the Nith River at New Hamburg, Ont.. The tab or It delimited fields of the files are the Julian date and year, month, and day for each observation and the daily mean value of streamflow, in $\mathrm{m}^{3} / \mathrm{s}$. The data were subsequently used in another study to perform hydrograph separation, which required the selection and separation of continuous blocks of daily mean streamflow data. Blocks of data are denoted chronologically in separate files by modifying the 3-digit file extension. For example, there are two discontinuities in the streamflow data for the Nith River at New Hamburg, Ont. and therefore the file 02GA018.000 was partitioned into three files (02GA018.001, 02GA018.002, and 02GA018.003). 


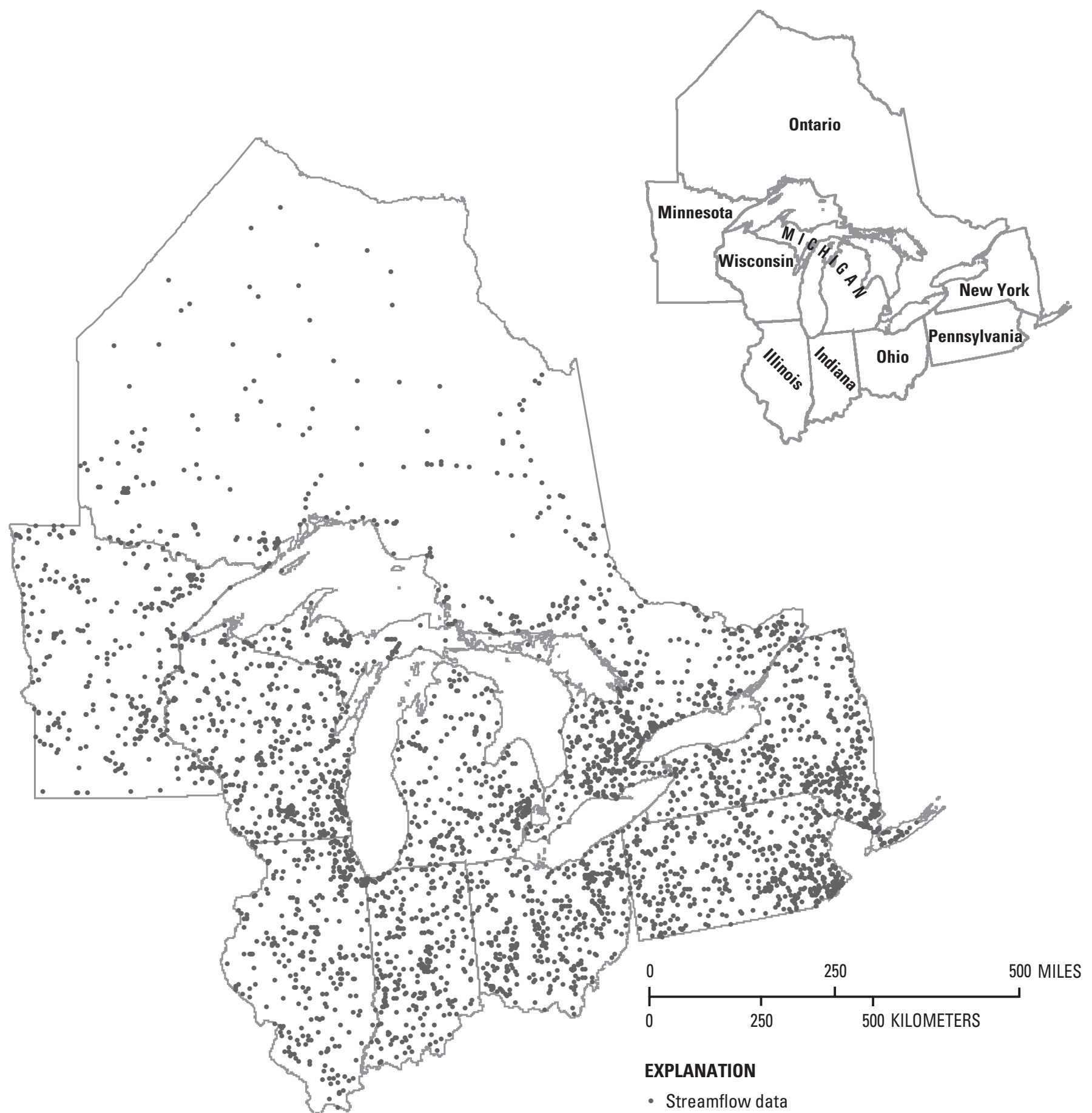

Figure 2. Spatial distribution of the streamflow data. 
Table 1. First 25 records of the streamflow gage file 02GA018.000 (Nith River at New Hamburg, Ont.).

[Delimiter, It, separates Julian date, year, month, day of month, and streamflow in $\mathrm{m}^{3} / \mathrm{s}$.]

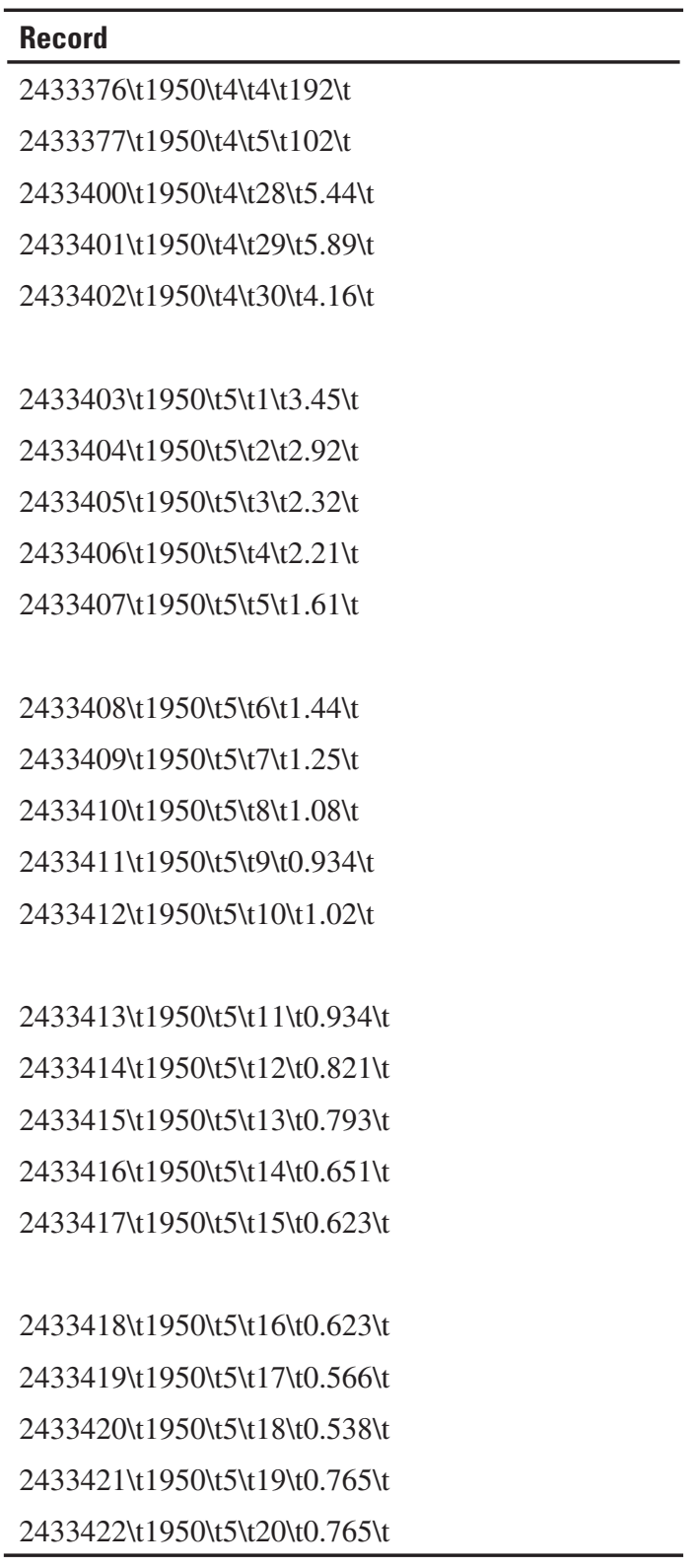

\section{Calculation of Streamflow Statistics}

Three groups of streamflow statistics were calculated. The first group consists of basic statistics and includes the number of daily values of streamflow for each gage and the maximum, mean, minimum, and standard deviation of the daily values (CNTVAL, MAXVAL,
MEANVL, MINVAL, and STDDEV, respectively). The second group consists of flow-duration statistics and includes the 5-, 10-, 25-, 50-, 75-, 90-, and 95-percentile flow-exceedance statistics (QEX05P, QEX10P, QEX25P, QEX50P, QEX75P, QEX90P, and QEX95P, respectively). The third group of streamflow statistics consists of n-day frequency statistics and includes the 1-day high-flow statistics with 5-, 25-, 50-, and 100-year recurrence intervals (H01005, H01025, H01050, and H01100, respectively) and the 7-day low-flow statistics with 2-, 5-, 10-, and 20-year recurrence intervals (L07002, L07005, L07010, and L07020, respectively).

The streamflow statistics were calculated using version 4.1 of the USGS SWSTAT software (Lumb and others, 1990), which reads streamflow data from Watershed Data Management (WDM) files and records the calculated values to the WDM files. Version 4.1 of the IOWDM software (Lumb and others, 1990) was used to create WDM files from the ASCII text files, and version 4.1 of the ANNIE software (Flynn and others, 1995) was used to extract the calculated values of the statistics from the WDM files. Version 4.0 of the LIBANNE software (Kittle and others, 1989) was used to compile SWSTAT, IOWDM, and ANNIE, and version 4.5 of the GLI software was used to compile SWSTAT and ANNIE. The statistics were calculated using the Linux operating system and therefore the Unix versions of the SWSTAT and IOWDM, ANNIE, and LIBANNE software were selected. Very few revisions to the source code were required to develop Linux implementations of the SWSTAT and IOWDM, ANNIE, and LIBANNE software using version 7.1 of Red Hat Linux and version 2.96 of the g77 FORTRAN compiler and to process the assembled streamflow data.

Creation of the WDM files and calculation and extraction of the statistics were coordinated using PERL programming where the details of the operations performed by SWSTAT and IOWDM and ANNIE were specified using command files. Tables 2 and 3 list the script (iowdm.pl) and command file (iowdm. $\log$ ) that were used to translate the ASCII text files (i.e., 02GA018.000) into WDM files (i.e., 02GA018.wdm). Tables 4, 5, and 6 list the script (basic.pl) and command file (basic.log) that were used to calculate the basic statistics and the command file (annie.log) that was used to extract the statistics from the WDM files. Tables 7 and 8 list the script (duration.pl) and command file (duration. template) that were used to calculate the flow-duration statistics where the values of MINVAL and MAXVAL, previously calculated for each gage, were used to derive duration.log from duration.template. Tables 9 and 10 list the script (frequency.pl) and command file (frequency. $\log$ ) that were used to calculate the n-day frequency statistics. 
Table 2. Perl programming script file iowdm.pl, used to translate ASCII text files (i.e., 02GA018.000) into WDM files (i.e., 02GA018.wdm).

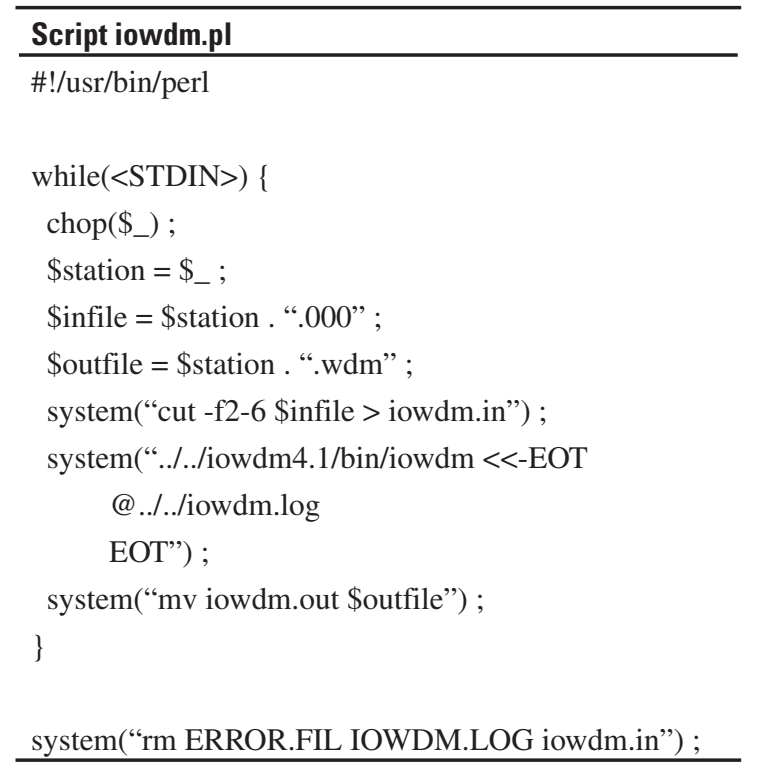

Table 3. Command file iowdm.log used to translate the ASCII text files (i.e., 02GA018.000) into WDM files (i.e., 02GA018.wdm).

\begin{tabular}{l}
\hline Command File iowdm.log \\
\hline fbiowdm.out \\
$\# 402$ \\
ritsoiowdm.in \\
$\# 402$ \\
fy,f9,m,f9,d,f9,v,f9 \\
$\# 402$ \\
t1860 \\
$\# 402$ \\
p \\
$\# 402$ \\
rrr \\
\hline
\end{tabular}

Table 4. Perl programming script file basic.pl, used to calculate the streamflow statistics.
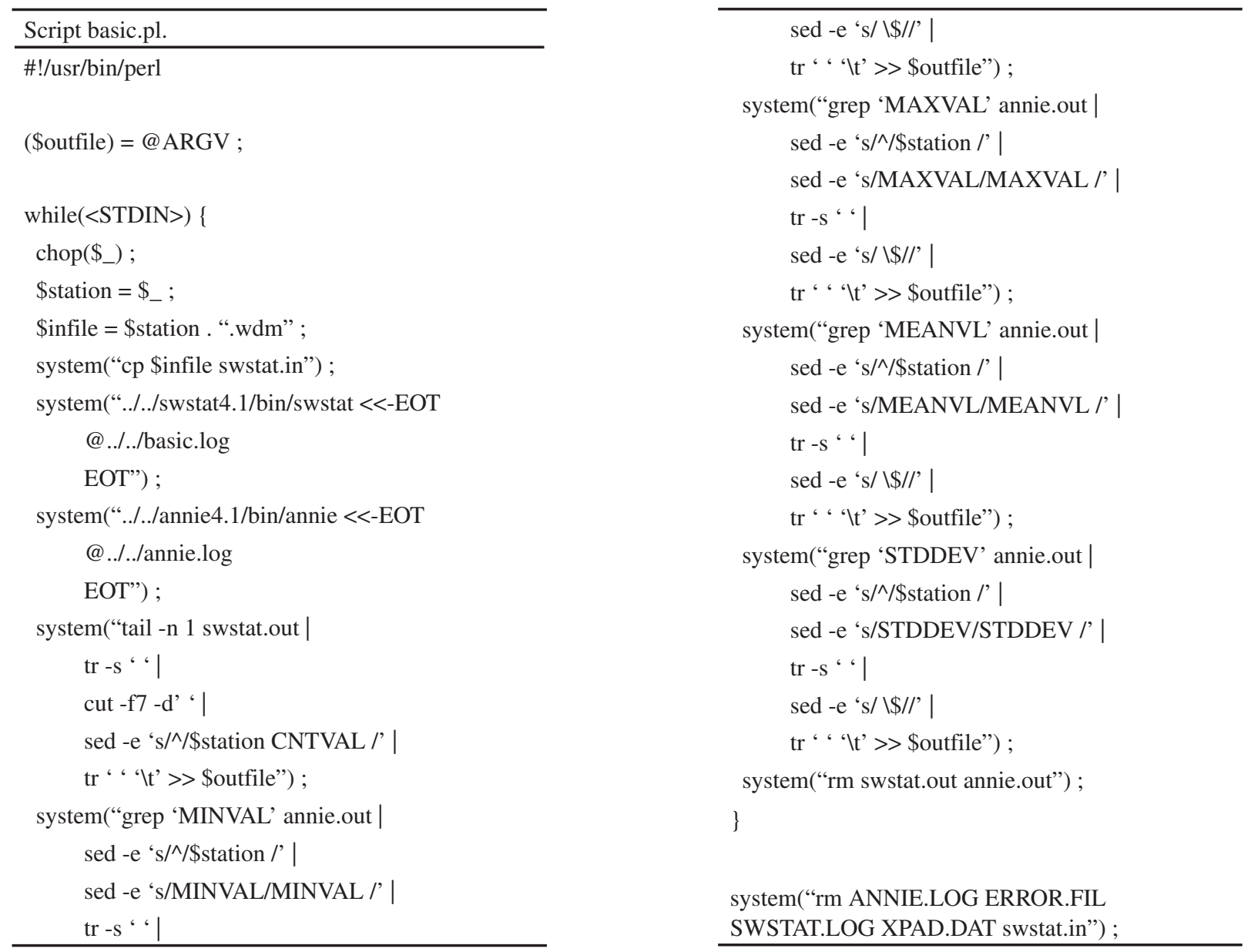
Table 7. Perl script duration.pl, used to calculate the flowduration statistics. (continued)

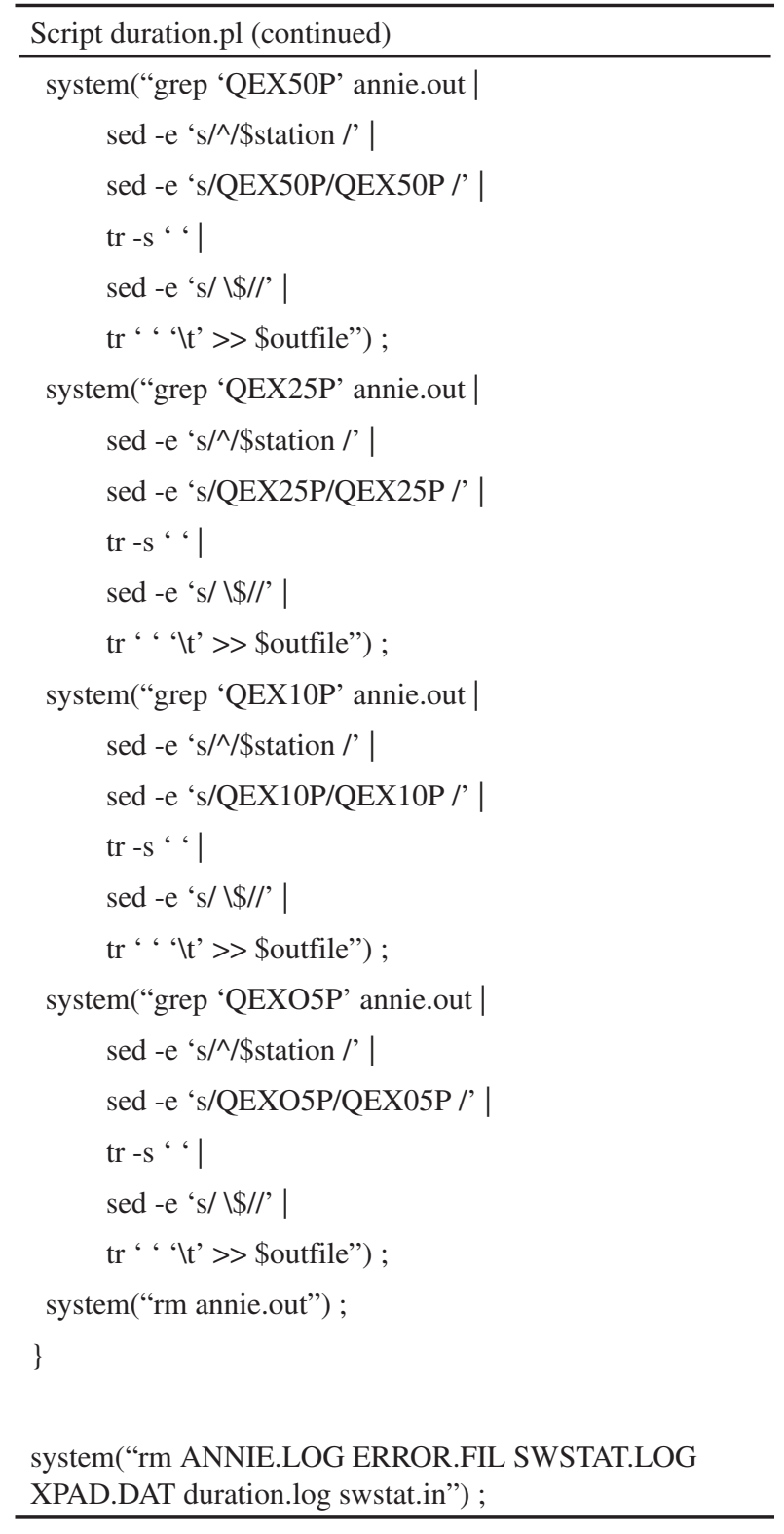

Table 8. Command file duration.template, used to derive duration.log.

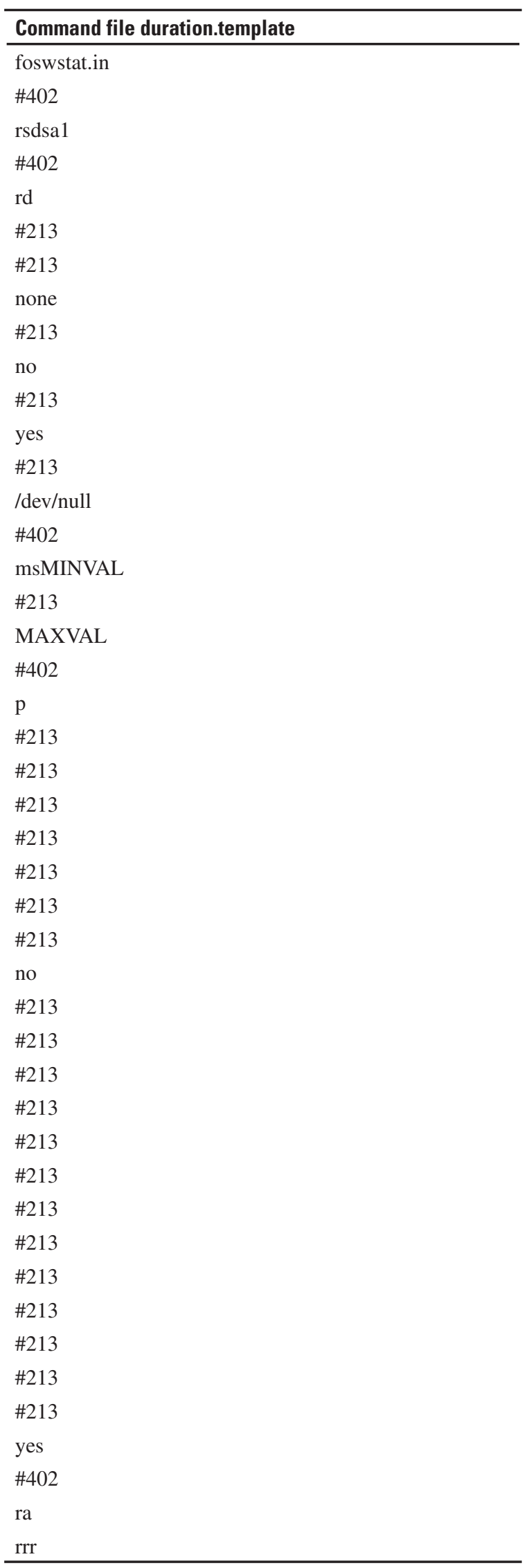


Table 9. Script frequency.pl, used to calculate the $\mathrm{n}$-day frequency statistics.
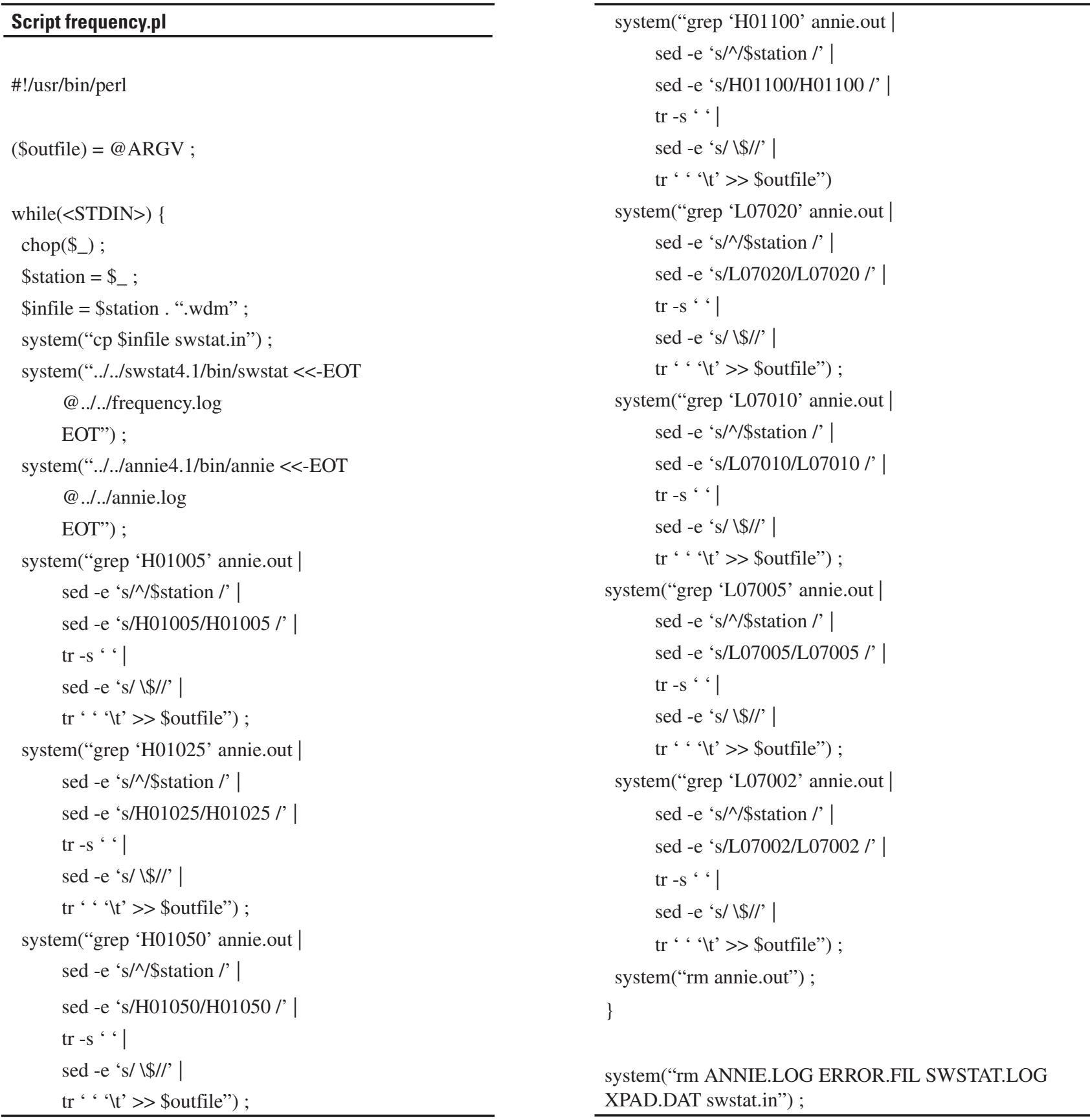
Table 10. Command file frequency.log, used to calculate the $\mathrm{n}$-day frequency statistics.

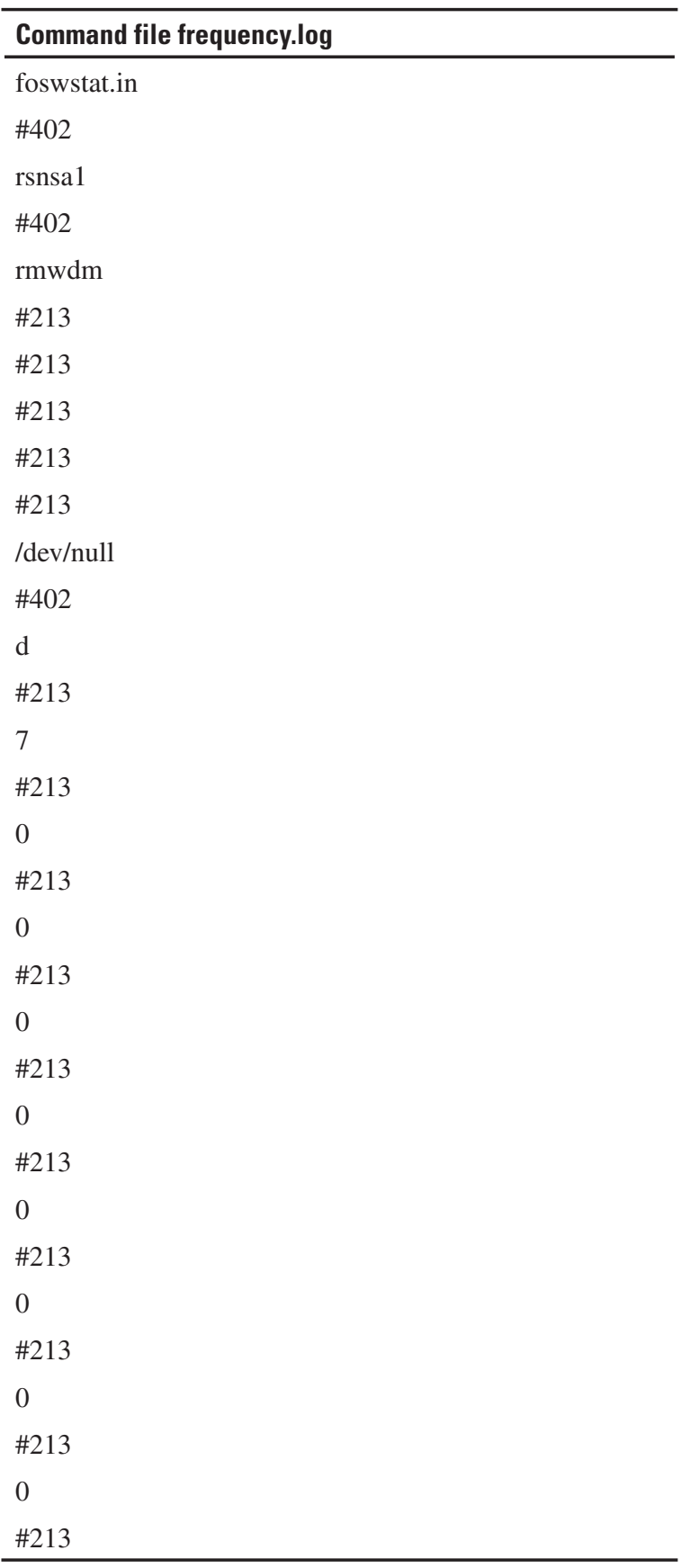

\begin{tabular}{l}
\hline 0 \\
$\# 213$ \\
0 \\
$\# 213$ \\
$\# 213$ \\
$\# 213$ \\
0 \\
$\# 213$ \\
0 \\
$\# 213$ \\
0 \\
$\# 213$ \\
0 \\
$\# 213$ \\
0 \\
$\# 213$ \\
0 \\
$\# 213$ \\
0 \\
$\# 213$ \\
0 \\
$\# 213$ \\
0 \\
$\# 402$ \\
arfsa501 \\
$\# 213$ \\
502 \\
$\# 402$ \\
ro/dev/null \\
$\# 213$ \\
no \\
$\# 402$ \\
arrr \\
\hline
\end{tabular}


Basic statistics were calculated for all of the streamflow gages. Flow-duration statistics were calculated for all streamflow gages, except for four streamflow gages in the Great Lakes states that have atypical data. Calculation of the n-day frequency statistics was limited to streamflow gages with at least five complete high-flow years (October 1 to September 30) and five complete low-flow years (April 1 to March 31) of data. Thus, n-day frequency statistics were calculated for 601 of the 779 streamflow gages in Ontario and 2,230 of the 3,157 streamflow gages in the Great Lakes states.

The statistics were calculated using the published units of the streamflow data; cubic meters per second $\left(\mathrm{m}^{3 / \mathrm{s}}\right)$ for Ontario and cubic feet per second $(\mathrm{ft} 3 / \mathrm{s})$ for the Great Lakes states. Figure 3 illustrates the calculated values of the basic statistics for the Nith River at New Hamburg, Ont. relative to streamflow for 1993. Only the maximum, mean, and minimum statistics (MAXVAL, MEANVL, and MINVAL) are absolute quantities that can be plotted on a hydrograph and, in this case, MIN$\mathrm{VAL}=0$ and therefore cannot be plotted using the semilogarithmic format of figure 3. Figures 4 and 5 similarly illustrate the calculated values of the flow-duration and n-day frequency statistics, respectively, relative to the streamflow data.
The streamflow gage attributes and basic, flowduration, and n-day frequency statistics were compiled into a single table for Ontario and a single table for the Great Lakes states. The tables were then output to the ASCII text files (ontario.txt and greatlakesstates.txt), which were used to create ESRI shapefiles for Ontario (ontario.dbf, ontario.sbn, ontario.sbx, ontario.shp, and ontario.shx) and the Great Lakes states (greatlakesstates. dbf, greatlakesstates.sbn, greatlakesstates.sbx, greatlakesstates.shp, and greatlakesstates.shx). These files and the accompanying files readme.txt and md5sum.txt are distributed with this report.

\section{Verification Exercises}

The SWSTAT and IOWDM and ANNIE software include series of tests that compare results calculated using an arbitrary implementation of the software to results calculated using a trusted implementation. All of the tests were successfully completed using the Linux implementations of the software that were used to calculate the streamflow statistics. The results of the tests for the implementation of the SWSTAT software were par-

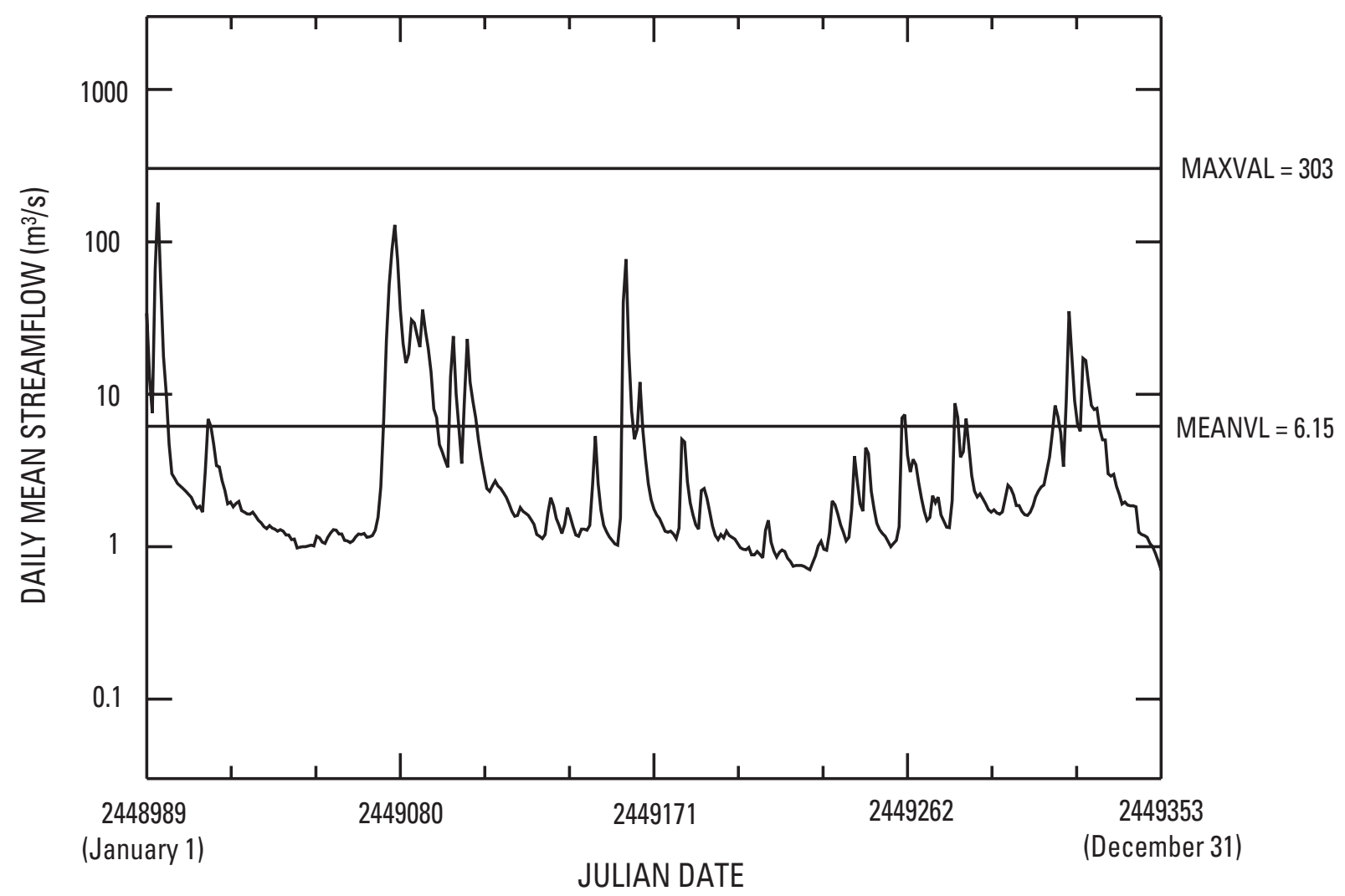

Figure 3. Calculated values of the maximum and mean statistics (MAXVAL and MEANVL) for the Nith River at New Hamburg, Ont. relative to total streamflow for 1993. 


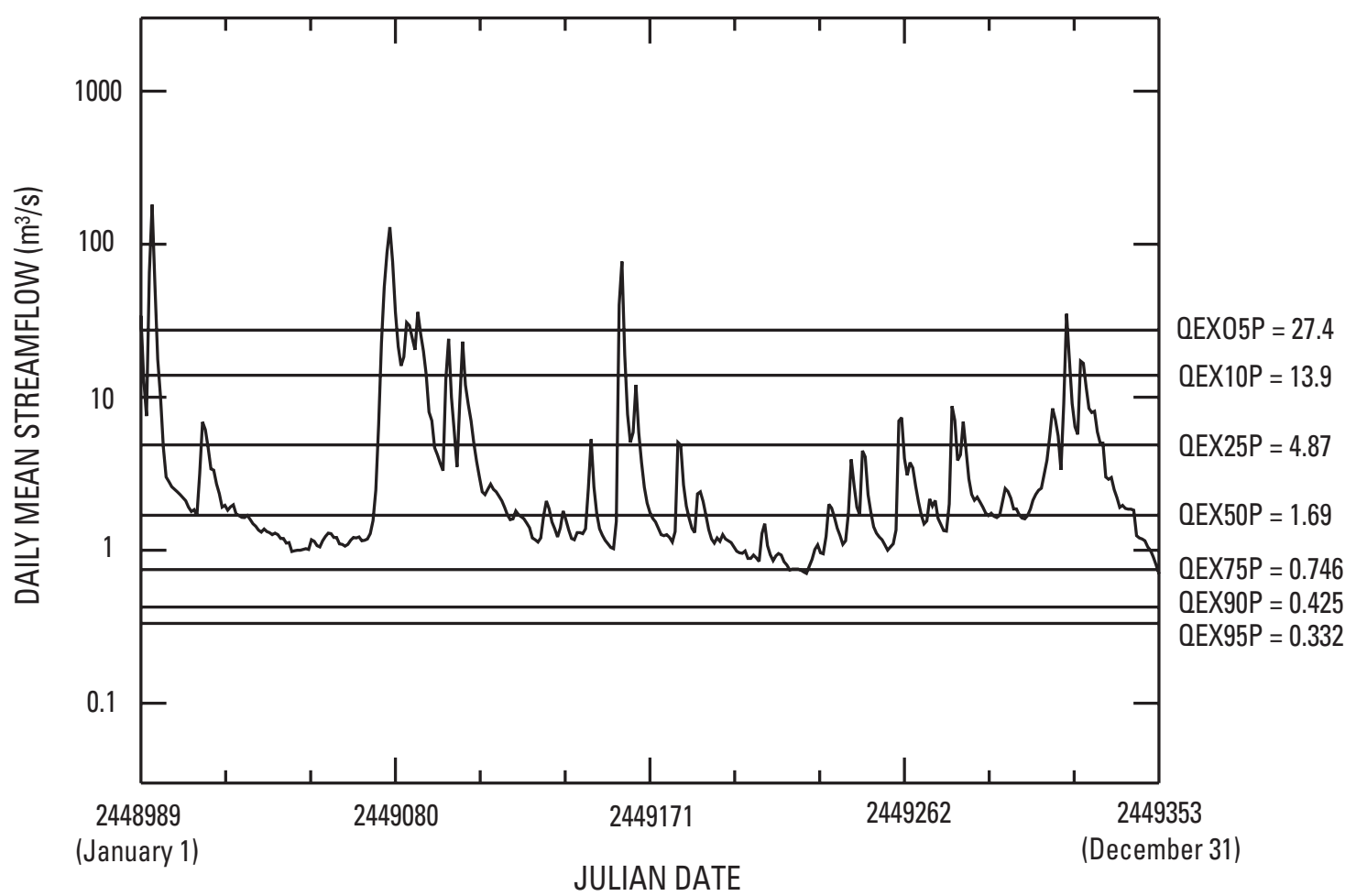

Figure 4. Calculated values of the flow-duration statistics (QEX05P, QEX10P, QEX25P, QEX50P, EX75P, QEX90P, and QEX95P) for the Nith River at New Hamburg, Ont. relative to total stream flow for 1993.

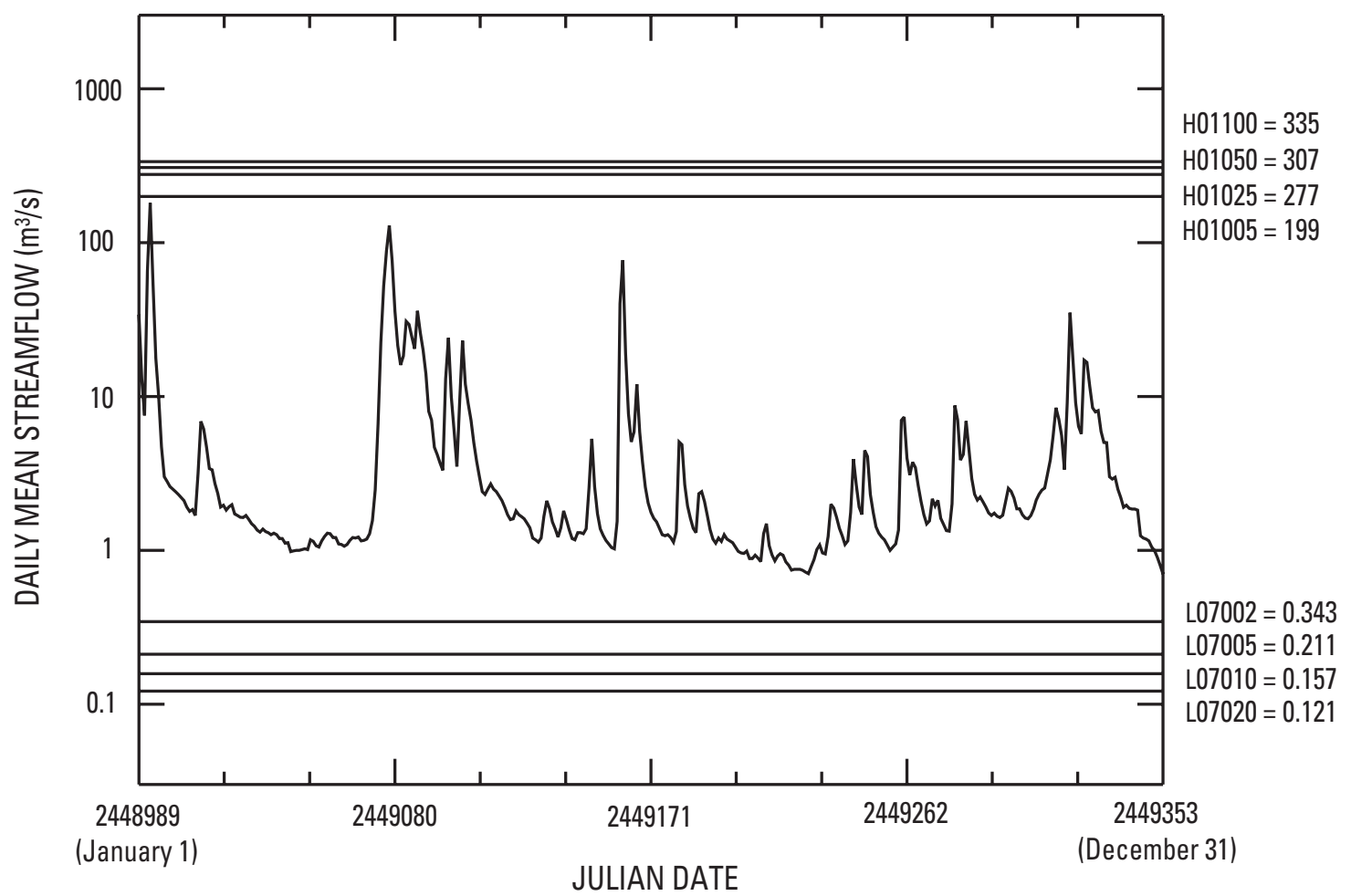

Figure 5. Calculated values of the n-day frequency high-flow (H01005, H01025, H01050, and H01100) and low-flow (L07002, L07005, L07010, and L07020) for the Nith River at New Hamburg, Ont. relative to total stream flow for 1993. 
ticularly carefully examined, and it was concluded that the few discrepancies that were observed were due to expected issues such as the differing dates of the calculations and inconsequential issues such as format related differences (e.g., "0." versus "0.000000") and computational precision related differences (e.g., "6454.339" versus “6454.338”).

Additional testing was performed by comparing the results calculated using the SWSTAT and IOWDM, ANNIE, and LIBANNE software to results calculated using other procedures and software. The basic statistics for all streamflow gages in Ontario were calculated directly from the ASCII text files and compared to the results calculated using the SWSTAT and IOWDM, ANNIE, and LIBANNE software. The two sets of results matched precisely, which verifies the translation of the ASCII text files into WDM files using iowdm.pl, iowdm.log, and IOWDM; the calculation of the statistics using basic.pl, basic.log, and SWSTAT; and the extraction of the results from the WDM files using annie. $\log$ and ANNIE. The flow-duration statistics were also calculated directly from the ASCII text files and compared to the results calculated using the SWSTAT and IOWDM, ANNIE, and LIBANNE software. The two sets of results compare very closely, which verifies the calculation of the statistics using duration.pl, duration. template, and SWSTAT. Finally, the 7-day 10-year recurrence interval low-flow statistic was calculated using the ASCII text files for a random sample of 60 streamflow gages using the U.S. EPA's DFLOW software (epa. gov/waterscience/dflow/) and compared to the results calculated using the SWSTAT and IOWDM, ANNIE, and LIBANNE software. The two sets of results compare closely, which verifies the calculation process using frequency.pl, frequency.log, and SWSTAT.

In addition, the 7-day 2- and 10-year recurrence interval low-flow statistics calculated using the SWSTAT and IOWDM, ANNIE, and LIBANNE software were compared to results calculated for a selection of streamflow gages using Environment Canada's LFA software. No significant discrepancy between the two sets of results for either of the two statistics was observed (Richard Pyrce, personal communication, 2005).

The results of these verification exercises appear to indicate that the calculation of the streamflow statistics using the Linux implementations of the SWSTAT and IOWDM, ANNIE, and LIBANNE software and the coordination of these calculations using the scripts and command files listed in tables 2 to 10 are accurate. No verification of the $n$-day frequency high-flow statistics was performed other than the tests that are included with the SWSTAT software, which appear to have been completed successfully.

\section{Acknowledgments}

The authors would like to thank Kathleen Flynn of the U.S. Geological Survey for her assistance in developing the Linux implementations of the SWSTAT and IOWDM, ANNIE, and LIBANNE software. The authors would also like to thank Paul Seelbach of the Michigan Department of Natural Resources and University of Michigan and Ian Cameron of the Ontario Ministry of Natural Resources for their assistance in specifying the streamflow statistics for calculation and Richard Price of Trent University's Watershed Science Centre for his assistance in verifying the statistics. Calculation of the streamflow statistics was made possible by Environment Canada's National Water Research Institute and Meteorological Service of Canada, the U.S. Geological Survey, and Great Lakes Protection Fund. Reviews of the manuscript were provided by Denis Healy and Steve Rheaume of the United States Geological Survey. Finally, Lori Fuller of the United States Geological Survey finalized the report layout and all figures.

\section{References Cited}

Environment Canada, 2002, HYDAT Version 2000 - 2.01, Surface water and sediment data: Water Survey of Canada, Meteorological Service of Canada, Environment Canada, Toronto, Ontario.

Flynn, K.M., Hummel, P.R., Lumb, A.M., and Kittle, J.L., Jr., 1995, User's manual for ANNIE, version 2, a computer program for interactive hydrologic data management: U.S. Geological Survey Water-Resources Investigations Report 95-4085, $211 \mathrm{p}$.

Kittle, J.L., Jr., Hummel, P.R., and Imhoff, J.C., 1989, ANNIE-IDE, A system for developing interactive user interfaces for environmental models (programmers guide): U.S. Environmental Protection Agency, EPA/600/3-89/034, Environmental Research Laboratory, Athens, Ga., 166 p.

Lumb, A.M., Kittle, J.L., Jr., and Flynn, K.M., 1990, Users manual for ANNIE, a computer program for interactive hydrologic analyses and data management: U.S. Geological Survey Water-Resources Investigations Report 89-4080, 236 p. (Documents the 1990 version of IOWDM included in the ANNIE program.) 

